\title{
Ways to Improve the Efficiency of Dump Trucks for Transporting Asphalt Mix
}

\author{
A.I. Dotsenko ${ }^{*}$ \\ ${ }^{1}$ Moscow Automobile and Road Construction State Technical University (MADI), Moscow (Russian \\ Federation)
}

The system of operational quality control of asphalt concrete road surface during its transportation is considered. The implementation of information technology is carried out with the help of GLONASS / GPS satellite system, which in real time mode allows you to capture the required parameters. Then this information is transferred to the integrated management system of asphalt concrete plant $(A C P)$. The system for monitoring parameters of asphalt concrete mixture is mounted on the basis of dump truck.

The developed integral monitoring of quality control of an asphalt-concrete with the use of GLONASS / GPS system provides to increase productivity and quality of work performed, can reduce the influence of the human factor on the quality of finished road surface, provides remote monitoring of main parameters of not only the technical means but also laying material during non-standard situation adjustment of system parameters ACP - DUMP TRUCK - ASPHALT CONCRETE.

\section{Keywords: Monitoring, GLONASS / GPS, Road-construction machines, Asphaltic concrete, Quality}

\section{INTRODUCTION}

Highways are a complex engineering and technical constructions, one of the most critical elements of which is the road surface. It is the condition of the road surface that determines the quality and service life of the road, and also ensures safe movement of vehicles.

One of the promising areas for improving the quality of roads is the comprehensive monitoring of the parameters of road-construction machines as well as stacked material in the process of performing construction operations.

The concept of monitoring in relation to control systems of road-construction machines includes a remote contactless method of parameter control. In monitoring systems, satellite systems are assigned the function of transmitting information in the forward and reverse direction from operating machines to remote control centres. The monitoring systems allow is accumulation of large volumes of information, which makes it possible to use tools to improve efficiency. To solve the above issues. it is necessary to modernize existing dump trucks or create a new specialized truck.

\section{THE OBJECT OF THE STUDY}

When considering issues related to improving of the quality of asphaltic concrete pavements, it should be taken into account that asphaltic concrete is a multicomponent structure, the final operational properties of which are affected by both factors related to the production of asphaltic concrete mixture at an asphaltic concrete plant (ACP), as well as an external one, in relation to production factors [1], namely:

Internal (production) factors

- Properties of the asphalt mixture components and their types;

- Recipe and structure of the mixture;

- Technology of the production of asphalt mixture;

External factors

- The quality of the road cover project;

- Quality of the road base;

- Technology of transportation, laying and compaction of the mixture.

Figure 1 shows a generalized process for the formation of the quality of asphaltic concrete pavement.

\footnotetext{
${ }^{*}$ Corresponding author: Moscow Automobile and Road Construction State Technical University (MADI), Leningradskiy Prospekt, 64, 


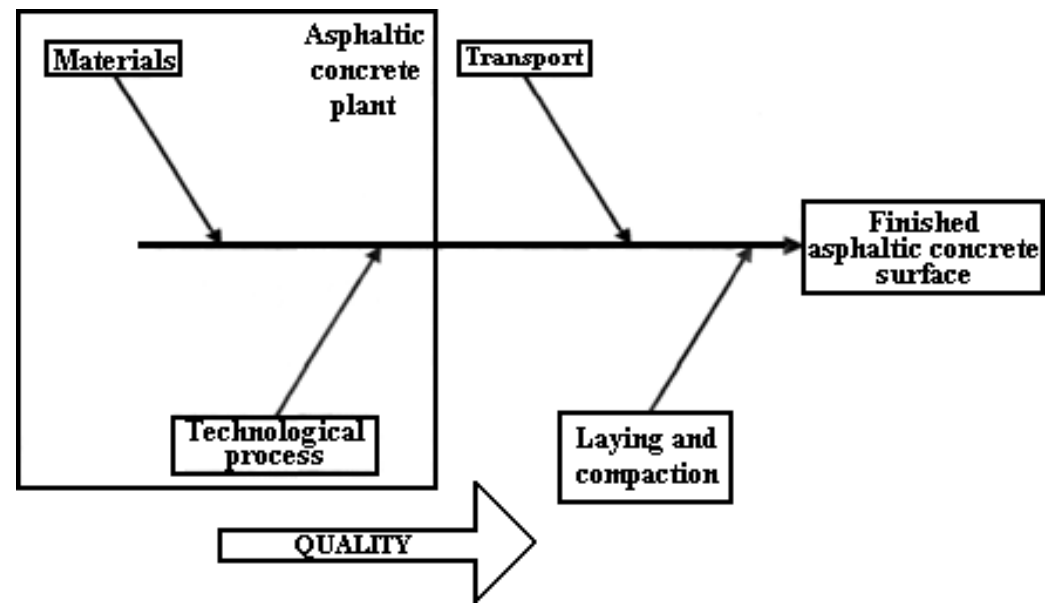

Figure 1: The generalized process of quality formation of an asphaltic concrete pavement

Now consider the individual components of the presented technological chain, significantly affecting the quality of the finished coating.

\subsection{Materials}

This part provides the information on the properties of all components of the asphalt mixture. It consists of the information contained in the passports for the components of materials, and the results obtained by the factory laboratory in the course of experimental studies on the actual properties of materials [2].

\subsection{Technological process}

This part provides information on the actual values of the process parameters [3], among which the most important are:

- Granulometric composition of each component of the asphalt mixture.

- Dosing error. batch.

- Actual mixture composition for each

- Temperature of bitumen, mineral materials, finished mixture at the outlet.

- Accuracy of control.

- Frequency of control.

- Systematic error of the control system.

- Methods and algorithms for processing of measurement results.

\subsection{Transport}

During the transportation of asphaltic concrete mixture, the following operations are carried out:

- Monitoring of the vehicle parameters dump truck (cargo mass, speed and direction of movement);
- Monitoring of the parameters of asphalt mixture (temperature in the upper and lower parts of the dump truck's body, in its side parts);

- The time of loading, delivery and unloading of the mixture;

- The rhythm of supplies;

- Fuel consumption level;

- Environmental conditions.

2.4. Laying and compaction of asphaltic concrete mixture

- Monitoring of paver's parameters (paving speed, fuel consumption level);

- Monitoring of the parameters of the asphalt mixture during installation (temperature and thickness of the layer to be laid);

- Monitoring of the parameters of the compacting machines (speed of the rollers, amplitude-frequency characteristics, the number of passes on one track, the level of fuel consumption);

- Monitoring of the parameters of the asphalt mixture during compaction (temperature, density);

- Environmental conditions.

To implement the above program, the dump truck must have the following additional equipment:

- Computer control unit

- Falcom F 35-XXL and antenna system Glonass /

GPS;

- Dump truck position control subsystem;

- Dump truck identification subsystem;

- Communication subsystem;

- Mixture temperature control subsystem;

- Ambient temperature control subsystem; 
- Wind speed sensor;

- Automatic system for covering the mixture with a tarpaulin in the body of a dump truck;

- Memory bloc;

-Manual data entry unit

The collected information from the dump truck is transmitted to the Central computer server of the asphalt concrete plant. This server, taking into account the current situation along the route of vehicle, as well as during the laying and compaction of the mixture, adjusts the operation mode of the factory equipment and ensures that the required quality of asphalt mixture is obtained at the outlet of asphaltic concrete plant. Figures 2 and 3 show the interaction in the process of monitoring of an integrated control system with the subsystems «Transport» and

«Laying and compaction».

By means of GLONASS/GPS system, you can determine the coordinates for both moving and stationary vehicles, calculate the maximum and average speed of movement, calculate the time after which the dump truck will be in a given place, find out the distance to the destination.

Currently, GSM cellular networks are an inexpensive alternative to traditional radio communication channels. In addition to reduction of the cost of use due to the absence of a license fee, such a solution simplifies and speeds up the development process, since it uses standard protocols and methods for transmitting information.

Information in GSM cellular networks can be transmitted:

- Via GSM voice channel;

- using GPRS;

- using SMS.

Advantages of GSM technology:

- the ability to quickly deploy the system anywhere with GSM coverage;

- high data rate;

- the principle of payment independence from the time of information transmission in the GPRS mode (payment is carried out not for the time, when the terminal is in the receivingtransmitting state, but for the amount of transmitted or received information).
- low cost when using SMS mode;

- easy customization;

- remote control capability.

There are two types of GSM modems:

- modules that are designed for direct installation in devices.

- modems that have their own enclosure.

If we compare modems with mobile phones, the former has a longer service life, higher reliability and sensitivity to the mobile network. Built-in modules and modems are designed to be embedded in the developer's end systems. In the simplest case, the presence of a built-in microcontroller assumes that the PC board should have only the appropriate circuits for matching with the environment - the power supply system (voltage converter, protection, filtering), transmitters, sensors, actuators, data reception/transmission interfaces (RS232, RS485, CAN). It significantly reduces the cost of the project and time expenditures.

GPRS modems often have a phase of several user inputs and outputs that fully support standard interfaces RS-232, USB, etc., as well as connectors for connecting an external antenna and other devices. In addition, modems have extensive capabilities for remote configuration of parameters and prompt programmed control of their operation. On the other hand, modems are made as easy as possible by eliminating such parts that are not used in this case, such as a microphone, speaker, display, keyboard, etc.

Among the GSM/GPRS/GPS modules and modems currently available on the market, there are several main series of remote collection and monitoring devices developed by both Russian and foreign specialists. Russian developments are represented by products of OOO Rateos, for example, the navigation controller «Azimut»; sensors for measuring asphalt-concrete mix temperature TSP/1- 1288; environmental temperature sensors TSP/1-8045.

Among the foreign equipment, we can name Falcom F35-XXL-SI terminal; the autonomous route recorder «Course GPS»; the GSM/GPRS modem Falcom SAMBA. 


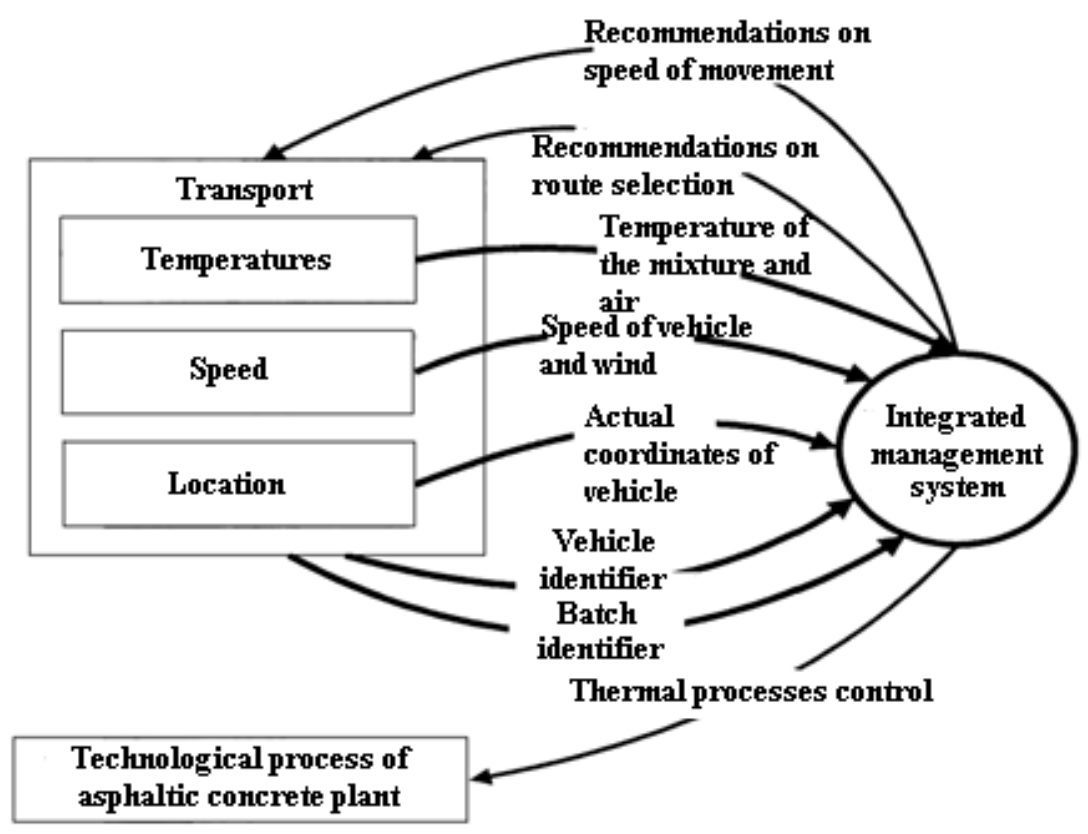

Figure 2: Interaction of an integrated management system with the subsystem «Transport»

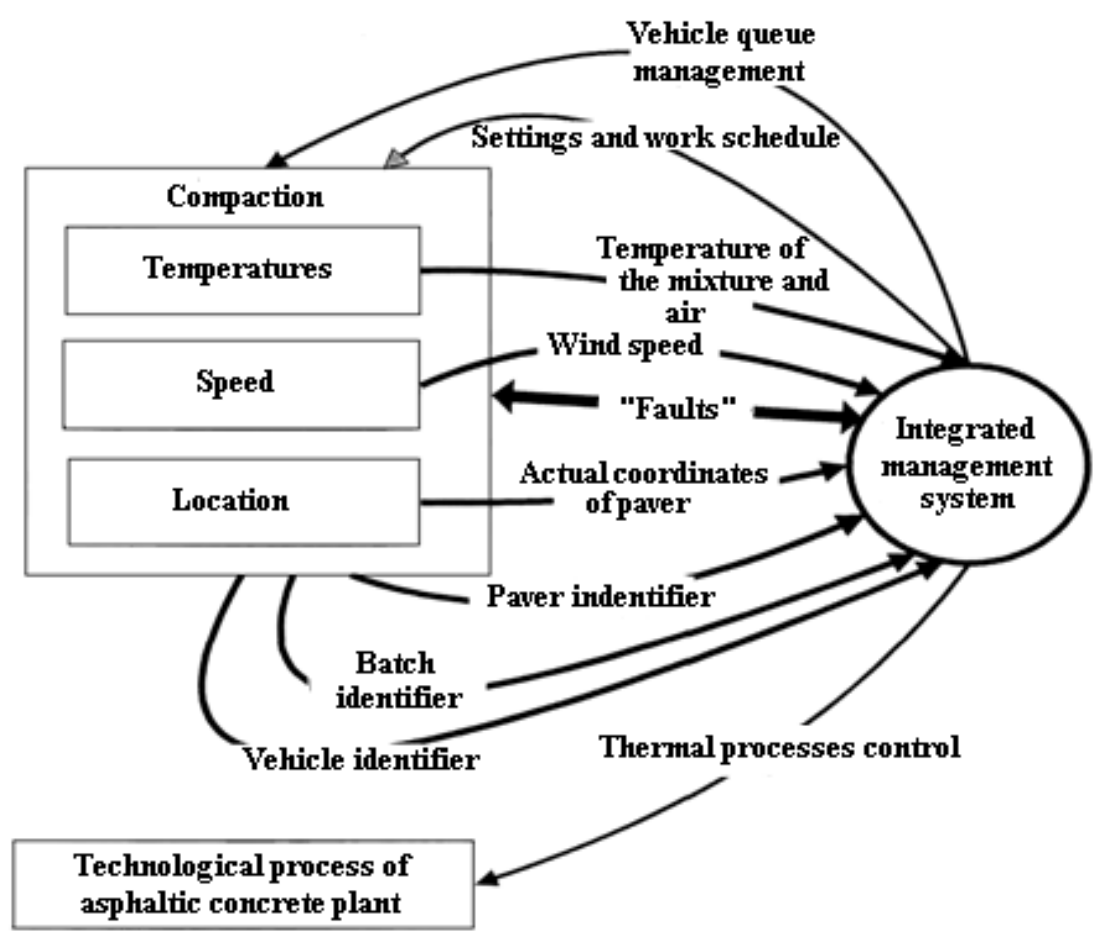

Figure 3: Interaction of an integrated management system with the subsystem «Laying and compaction» 


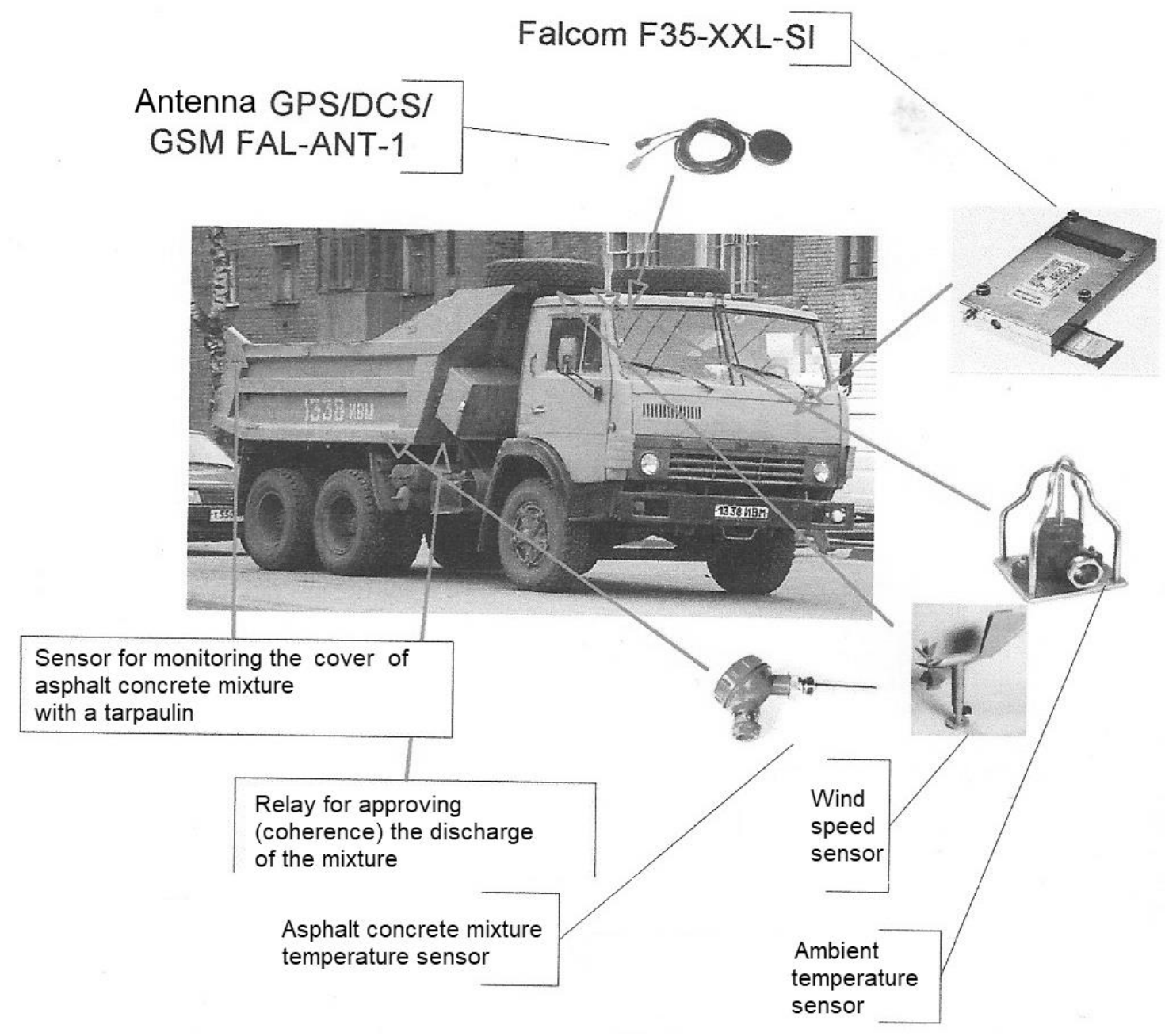

Figure 4: KamAZ 55118 dump truck with a system for monitoring parameters of asphalt concrete mixture during its transportation.

Figure 4 shows a KamAZ 55118 dump truck with a system for monitoring parameters of asphalt concrete mixture during its transportation.

It should be noted that as a result of monitoring, a significant array of data is generated, and its processing requires lengthy computing resources. So, for each truck after receiving its actual coordinates, it is necessary to determine the position on the ground, the average speed in the last segment, the average speed from the start of movement, as well as the presumable total delivery time and temperature fields in the truck body.

Figure 5 presents a generalized algorithm for controlling the transportation of asphaltconcrete mix. This algorithm includes three subroutines:

- mix loading;

- monitoring the parameters of the dump truck and the mix during its transportation;
- monitoring the car parameters during the return to the ACP.

After loading the car in the integrated management system of ACP, a route chart is formed with the following parameters: the car number, the object, the initial characteristics of the asphalt-concrete mix.

The main subroutine in the algorithm is the monitoring of parameters during the movement of the dump truck (Fig. 6). When starting the subroutine, the following parameters are determined: the location coordinates, the readings from the temperature sensors of the mix and the environment. The collected data are formed into a batch and transmitted to the integrated management system of ACP (control point).

Upon receiving these data, the control point sends a confirmation of receipt. The received materials are processed using the TranMaster program. Then the position of the dump truck on the map is determined and the temperature of the 
asphalt-concrete mix is monitored. If the temperature does not correspond to the set value for this mix grade, the control point corrects the route and parameters of the car movement or may decide to return it to the ACP.

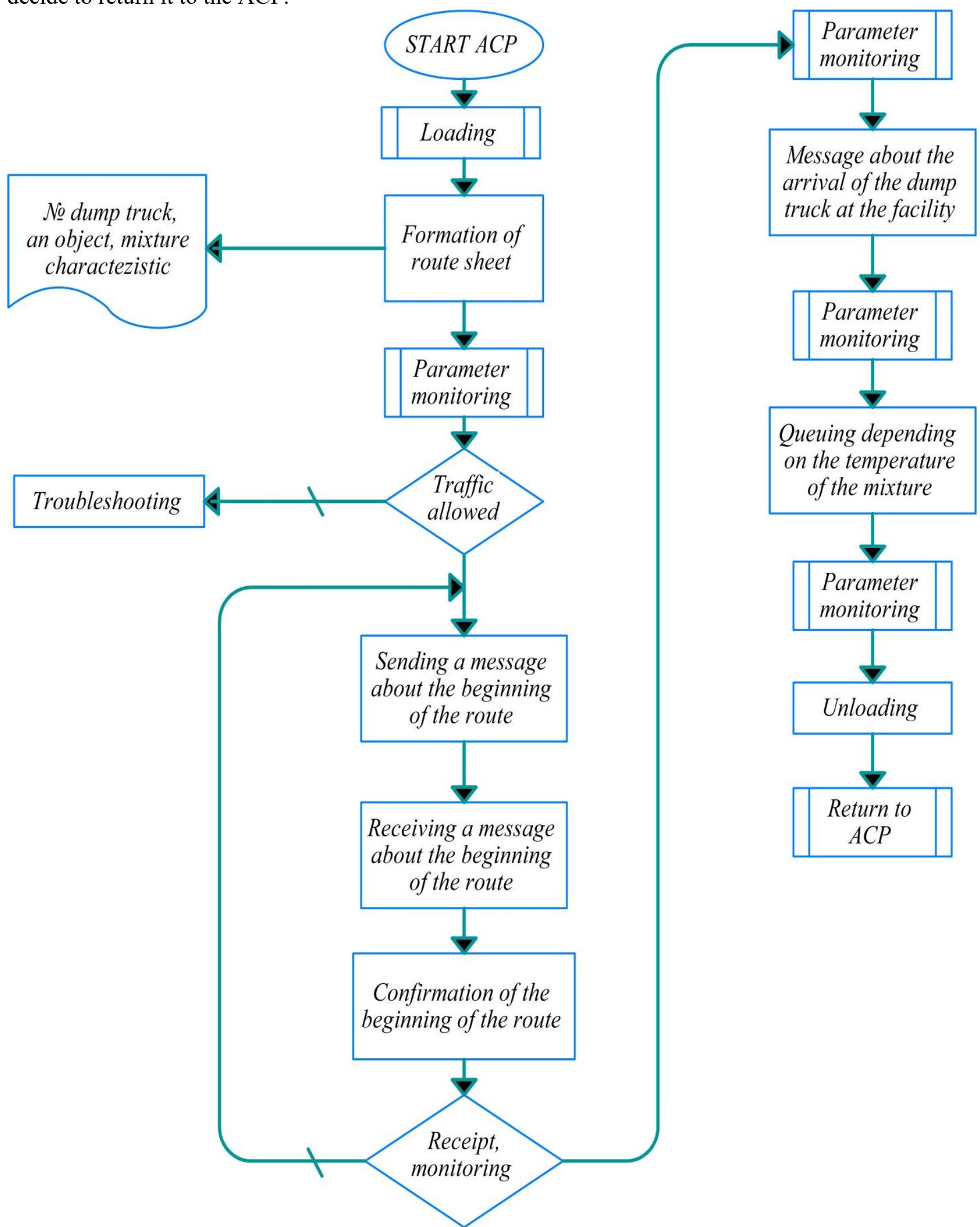

The software allows the user to receive the satellite monitoring data from the $« \mathrm{ACP}-\mathrm{DUMP}$ TRUCK-ASPHALT CONCRETE» system in the form of visual reports, graphs and tables. 


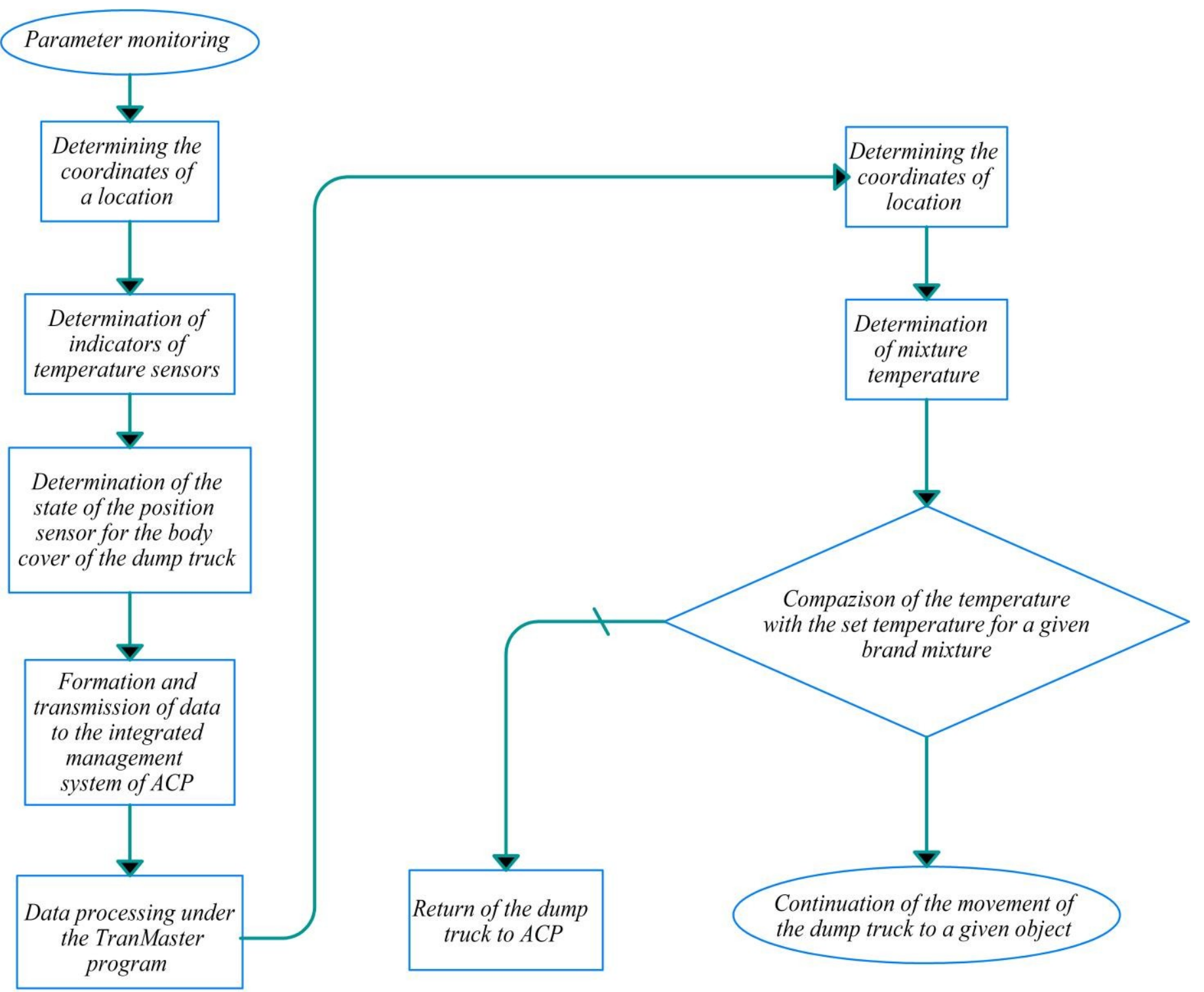

Figure 6: Subroutine of monitoring the parameter of the dump truck and the mix during its transportation.

The system for monitoring parameters of

\section{CONCLUSION}

Integrated monitoring of the parameters of dump truck and asphalt mixtures with using of the GLONASS system provides an increased productivity of the work performance, reduces the influence of the human factor on the quality of the finished road surface, and it becomes possible to carry out the remote control of the main parameters of not only the vehicles, but also the laid material, as well as operational response to the adjustment of the "ACP-DUMP TRUCKASPHALT CONCRETE» system parameters in case of emergency. dump truck for transporting asphalt mix, developed at the Moscow Automobile and Road Construction University, is being successfully implemented at construction sites of Russian Federation.

\section{REFERENCES}

[1]A.I. Dotsenko, A.V. Rudensky, "The Concept of Integrated Quality Management of Asphaltic Concrete Roads", Mechanization of Construction, Vol. (6), pp. 17- 20, (2011)

[2]N.V. Gorelyshev, "Asphaltic Concrete and Other Materials", Mozhaysk-Tera, Moscow (Russia), (1995) 
[3]V.N. Shestakov, V.B. Permyakov, V.M. Vorozheikin, "Technological Support for the Quality of Construction of Asphaltic Concrete Pavements: Method, Recommendations", SibADI, Omsk (Russia), (1999)

\section{Načini poboljšanja efikasnosti} kipera za transport asfaltne mešavine

\author{
A.I. Dotsenko ${ }^{1 *}$
}

${ }^{1}$ Moskovski državni tehnički Univerzitet za automobile i konstrukciju puteva (MADI), Moskva (Ruska Federacija)

Razmatran je sistem operativne kontrole kvaliteta asfaltne mešavine tokom njenog transporta. Implementacija informacione tehnologije se vrši uz pomoć GLONASS/GPS satelitskog sistema, koji u režimu realnog vremena omogućava dobijanje potrebnih parametara. Nakon toga se ove informacije prenose u integrisani sistem upravljanja fabrikom asfalta (ASR). Sistem za praćenje parametara asfaltno betonske mešavine montiran je na šasiji kipera.

Razvijeno integralno praćenje kontrole kvaliteta asfalt-betona uz upotrebu GLONASS/GPS sistema omogućava povećanje produktivnosti i kvaliteta obavljenog poslai može smanjiti uticaj ljudskog faktora na kvalitet gotove površine puta $i$ omogućiti daljinsko praćenje glavnih parametra ne samo tehničkih sredstava već $i$ materijala za polaganje pri nestandardnoj situaciji prilagođavanje parametara sistema ASR - KAMION - ASFALT BETON.

Ključne reči: Monitoring, GLONASS / GPS, Mašine za puteve, Asfaltni beton, Kvalitet 